\title{
Trial Arm Branch
}

National Cancer Institute

\section{Source}

National Cancer Institute. Trial Arm Branch. NCI Thesaurus. Code C83437.

A particular division of a trial arm. 